This is an open access article under the CC BY-NC-ND license Issue IV, 22 November 2021 e-ISSN 2707-9481 Institute of Metallurgy and Ore Beneficiation, Satbayev University, Almaty, Kazakhstan

Uteshkalieva Aigul

Candidate of Pedagogical Sciences, assoc. Professor Atyrau University named after Kh. Dosmukhamedov Email: aigul_bekbol@mail.ru https://orcid.org/0000-0002-7571-6279
Saginova Batima

Graduate student of Atyrau University named after

Kh. Dosmukhamedov, specialty 7M01301

"Management in education"

Email: batima1997@bk.ru

https://orcid.org/0000-0002-9396-6474

\title{
Formation of teachers of the initial stage of education - readiness for innovation
}

\begin{abstract}
This article examines the readiness and formation of teachers of primary education - innovative activity. The relevance of this topic lies in the search and application of innovative technologies in primary schools, where the main task of teachers is to quickly adapt to modern innovations and the ongoing changes in updated education. The XXI century is called the century of high or digital technologies, and therefore creative, active, fast-learning and inquisitive people are in demand in any industry. The modern system of updated education develops children's research and cognitive structure of activity. In this regard, adjustments are made to the educational program in almost every country to develop students' abilities, based on research and cognitive activity, where one of the first steps is primary school.
\end{abstract}

Cite this article as: Uteshkalieva A.; Saginova B. (2021). Formation of teachers of the initial stage of education - readiness for innovation. Challenges of Science. Issue IV, pp. 109-112. https://doi.org/10.31643/2021.17

\section{Introduction}

To date, the education system is in search of innovative ways of updated education. One of the most important tasks is the ability of teachers to react sensitively and quickly adapt to changes in practice. This is due to the need to make managerial decisions that ensure a number of professional changes of the teacher, which may reflect the needs of a modern school both in organizational, pedagogical and social terms.

\section{Literature review}

Given the experience and age of many teachers, we can say that they are experiencing serious difficulties in implementing innovative and digital activities, which complicates the process of their adaptation to the requirements of modern schools and reduces the effectiveness of their work. It should be emphasized that the activities of primary school teachers to develop educational programs in accordance with the current updated program and online training in connection with the pandemic are innovative. This, in turn, requires teachers to have the skills to design programs that support this process. In this regard, the question arises about the need to increase the level of readiness of teachers for innovation and the search for effective means of solving this problem on the part of the head of the educational institution. There is a huge amount of work on the subject of innovation, the development of new methods, variations and improvements of existing ones, as well as the constant, urgent interest of researchers in this task. 
According to the studied problem, various directions of research of innovative activity are reflected in the scientific and pedagogical literature: general and specific features of creative activity are considered in the works of V.I. Zagvyazinsky [1], A. Aitpaeva [2], Danilov D.A.[3]; from the point of view of studying pedagogical achievements and spreading best practices, innovative activity of a teacher is studied by A.M. Bakhtyzin [4]; N.R. Yusufbekova [5]; features of innovative phenomena in the modern education system are considered: A.P. Panfilova [6]; A. P. Usoltsev [7];

For many years, the methodology of primary school teaching has been constantly searching for innovative teaching methods that contribute to the activation of educational and cognitive activity of younger schoolchildren. Innovation is the introduction of new methodologies and standards into the educational process. Obedience, repetition, imitation are replaced by new requirements: the ability to see problems, calmly accept them, and solve them independently. This applies to all spheres of life: household, social and professional. Correlating the concept of "innovation" with the pedagogical process, the term innovation means the introduction of fundamentally new goals, content, methods and forms of educational activity. In the pedagogical encyclopedia [8], the concept of "pedagogical innovation" is considered as an innovation in pedagogical activity, a change in the content and technology of teaching and upbringing aimed at increasing their effectiveness"

Innovations become possible due to the introduction into professional activity of didactic and educational programs unknown to practice, which presupposes the removal of the pedagogical crisis. The development of the ability to motivate actions, independently navigate the information received, the formation of creative unconventional thinking, the development of children through the maximum disclosure of their natural abilities, using the latest achievements of science and practice- are the main goals of innovation. Innovative activity in education, as a socially significant practice aimed at moral self-improvement of a person, is important because it is able to ensure the transformation of all existing types of practices in society. When choosing a teaching style, the teacher's beliefs have a greater influence than his knowledge, because in the learning process they influence everything he does in the classroom, beliefs to accept new ideas, so I completely revised my teaching methodology before and after. The modern requirements of society for the teacher are such that the teacher must constantly engage in self-education, expanding the boundaries of their capabilities. He should be able to change quickly and be able to apply new approaches and technologies in the classroom. In a word, the teacher must keep up with the times.

Innovative technologies are capable of modernizing the educational process as a whole and directing it to achieve learning outcomes, replacing the accustomed traditional learning system, which is primarily based on reproductive learning. It is also important to consider such a concept as "psychological readiness for innovation", which is characterized by a holistic psychological aspect, representing the unity of the cognitive component (knowledge in the field of innovation, forms, methods, modern educational technologies and pedagogical tools), emotional (positive attitude to innovations) and activity components [9].

Also, special attention should be paid to the teacher's readiness for innovative activities aimed at improving professional activity, as well as the ability to identify existing problems in the training and education of students, effectively solve them and eliminate mistakes.

That is, an innovator teacher should be focused on creating his own creative tasks, methods and set up for innovative activity. It is important to be prepared to overcome the difficulties associated with the content and organization of innovation activities. It is necessary to master the skills of mastering pedagogical innovations, to be able to develop their own innovations, using different techniques during the lesson, such as "Right, wrong statements", the game "Do you believe?", Bloom's daisy, basket of ideas, cluster, insert, thick and thin questions, cinquain, embodiment (in the role of a person, animate or inanimate being), business game, dialogue of historical or literary characters, illustrative comparison of facts, documents, events, epochs, civilizations, dramatization a real or fictional historical event, a journey, role-playing game, quizzes, etc.

Primary school teachers are called upon to teach children creativity, to educate in each child an independent personality who owns the tools of self-development and self-improvement, who is able to find effective ways to solve problems, search for the necessary information, think critically, engage in discussion, communication, but of course, the nature of the innovative activity of a teacher depends on the teacher himself and his level of personal readiness for this activity, but the conditions provided for its development 
are not unimportant. The main result of innovative learning is the development of the child's personality on the basis of educational activities, "it is necessary that the child learns about himself as a person, and his interests coincide with universal values" [10].

\section{Research Results}

This result, we believe, is possible through the introduction of modern educational technologies into the practice of primary school teachers, allowing them to solve the task of modern innovative education the upbringing of a socially active personality.

Undoubtedly, traditional tools have become insufficient to achieve these goals, and teachers are not ready for innovative activities at all. The question arises, how to help teachers to be ready for innovation.

For the effectiveness of innovative activity and systematic methodological work with the teaching staff to improve their professional competence, it is necessary:

$>$ the teachers of an educational institution have an individual development plan that mobilizes their expected abilities and capabilities;

$>$ systematic accounting of teacher's successes in pedagogical activity and achievements in the work of teachers;

$>$ creating a creative environment for the teacher and combining the efforts of the entire teaching staff to build an educational space where each teacher could realize their importance;

$>$ establishing a trusting, direct relationship in which the teacher will lose the fear of being misunderstood by colleagues and management.

$>$ properly structured work of the head of an educational institution for the expansion and implementation of innovative activities in an educational institution.

$>$ conducting scientific and methodological seminars between teachers, round tables, exchange of new ideas, advanced training courses, etc.;

$>$ consistency, creating a situation of success, creating a creative atmosphere, etc.

So, the formation of readiness for innovative activity among teachers of the initial stage of education will allow to activate the activity of teachers, attract them to work together, mobilize the creative potential of primary school teachers, help the teacher's personality self-actualize, select the most effective teaching methods and techniques, means that contribute to the activation of the mental activity of younger schoolchildren.

\section{Conclusion}

The use of innovative research methods in the educational process, discussions, cognitive games, integrated lessons with the use of ICT opens up the possibilities of cognitive research activity of students. Professional competence, pedagogical skills, intellectual and moral character of a teacher, are one of the main conditions for the effectiveness of the educational process. Thus, the formation of readiness for innovative activity among teachers of the initial stage of education will allow to activate the activities of teachers, attract them to work together, mobilize the creative potential of primary school teachers, help the self-realization of the teacher's personality, select the most effective teaching methods and techniques, means that contribute to the activation of the mental activity of younger schoolchildren. The use of innovative research methods, discussions, cognitive games, integrated lessons with the use of ICT in the educational process opens up opportunities for cognitive research activities of students. Professional competence, pedagogical skills, intellectual and moral character of a teacher are one of the main conditions for the effectiveness of the educational process.

Cite this article as: Uteshkalieva A.; Saginova B. (2021). Formation of teachers of the initial stage of education - readiness for innovation. Challenges of Science. Issue IV, pp. 109-112. https://doi.org/10.31643/2021.17 


\section{References}

1. Zagvyazinsky V.I. (2015) On the connection of methodology and technology in pedagogical research. Education and science.;(5):4-14. https://doi.org/10.17853/1994-5639-2015-5-4-14

2. Aitpaeva, A. (2021). The activity approach is a practice-oriented tactic of training future teachers. InterConf, (49), $231-240$. https://doi.org/10.51582/interconf.7-8.04.2021.022

3. Danilov D.A. (2016) Conceptual approaches to personification of students' preparation for professional and pedagogical activity.// Siberian Pedagogical Journal Issue No6.,.

4. Bakhtyzin, A.M. (2008). Innovative processes in modern education: essence, problems, prospects / A.M. Bakhtyzin // Psychopedagogy. -- No. 4. - p. 67.

5. Yusufbekova, N. R. (1991) Trends and laws of innovative processes in education / N. R. Yusufbekova // New research in pedagogical sciences. - 1991. - No. 2. - pp. 6-9.

6. Panfilova A.P. (2018) Innovative pedagogical technologies: Active learning https://www.twirpx.com/file/365127/

7. Usoltsev A.P. (2019) INNOVATIVE ACTIVITY OF TEACHERS - MYTH OR REALITY? https://elar.rsvpu.ru/bitstream/123456789/29634/1/edscience_2019_5_003.pdf

8. Pedagogical Encyclopedia https://didacts.ru

9. Slastenin, V. A. (1997) Pedagogy: innovative activity [Text] / V. A. Slastenin, L. S. Podymova. - M. : ICP "Publishing House of the Master", - $224 \mathrm{p}$.

10. CHIZHMAN O.V. (2019) The impact of innovative activity on improving the professional competence of a teacher https://www.elibrary.ru/item.asp?id=41898944 